\title{
PRINCIPAL COMPONENT ANALYSIS AND THERMOMECHANICAL PREFERENCE OF WHITE Au ALLOYS WITHOUT Ag
}

\author{
MLADEN MIRIĆab, BILJANA ARSIĆc, ${ }^{*}$, \\ MILOŠ ĐORĐEVIĆb, DRAGAN ĐORĐEVIĆ \\ DRAGOSLAV GUSKOVIĆa, SVETLANA IVANOV ${ }^{a}$
}

\begin{abstract}
Addition of different amounts of $\mathrm{Cu}$ and $\mathrm{Ag}$ to $\mathrm{Au}$ alloys, as well as some new elements ( $\mathrm{Zn}$ and $\mathrm{Cd}$ ), gives alloys of the different colour spectrum (from red to yellow) and different technological and metallurgical characteristics. The trend today is the implementation of new alloys not containing $\mathrm{Ag}$, and including new elements, such as $\mathrm{Ga}$ and In. Differences in two Au alloys exist: the first alloy contains $\mathrm{Ni}$ and $\mathrm{Pd}$, and the second alloy is without them. The values of electrical conductivity and hardness are different, due to the reduction, which was shown using PCA ( $r=0.985$ and the strong positive correlation between hardness and electrical conductivity). Performed tests confirm that those multiphase multi component gold alloys can find their application not only in jewellery making but also in the world of modern electrical engineering. The performed statistical analysis shows strong positive and negative correlations of properties of investigated Au alloys, and it provides significant savings in the design and efficiency of metallurgical processes.
\end{abstract}

Keywords: alloy, PCA, metallurgical process.

\section{INTRODUCTION}

The subject of this work, through the prism of processing metallurgy and legal metrology, was to determine the conditions for obtaining semifinished products in jewellery with a suitable equivalent axial structure (with

a University of Belgrade, Technical Faculty Bor, Vojske Jugoslavije 12, 19210 Bor, Republic of Serbia

b Department of Chemistry, University of Niš, Faculty of Sciences and Mathematics, Višegradska 33, 18000 Niš, Republic of Serbia

c Department of Mathematics, University of Niš, Faculty of Sciences and Mathematics, Višegradska 33, 18000 Niš, Republic of Serbia

* Corresponding author: biljana.arsic@pmf.edu.rs 
MLADEN MIRIĆ, BILJANA ARSIĆ, MILOŠ ĐORĐEVIĆ, DRAGAN ĐORĐEVIĆ, DRAGOSLAV GUSKOVIĆ, SVETLANA IVANOV

the crystal grains of the same crystallographic orientation, and the grains about the same shape and boundaries), and optimal physico-chemical and mechanical properties. Our first aim, in the framework of this task, was to obtain multicomponent alloys of gold and white colours for melting and casting and then investigate their formation in the solid state. The method of cold rolling of the molded pieces in combination with certain annealing processes gives plastic properties for the material that are optimal for cold rolling and drawing, as well as further cold deformations of samples.

The latest medical and technological achievements led us to focus, in this paper, on so far poorly investigated 585 alloys of gold for white jewellery, without Ag, mostly in the form of annealed and cold-deformed sheet, strip, tube and wire [1,2]. The investigated gold alloys are of quantitative composition Au585Cu312Zn40Ga35In28 (white and reddish-gray colour) and Au585Cu233Ni80Zn70Pd32 (white-gray colour).

Regarding applied statistical analysis tool, we used non-parametric analysis - principal component analysis (PCA) in order to obtain the initial solution reducing the original dataset [3-5]. The earliest works in principal component analysis can be found in Karl Pearson (1901) [6]. In chemistry, PCA was firstly introduced by Malinowski in 1960s as a principal factor analysis [7].

In this work, we used microstructural analysis, metallography with optical microscopy and scanning electron microscopy (SEM) with energy-dispersive spectroscopy (EDS) in combination with principal component analysis (PCA), and contributed to better understanding of new Au alloys.

\section{RESULTS AND DISCUSSION}

A cold-rolled sheet of alloy Au585Cu233Ni80Zn70Pd32 (thickness $0.38 \mathrm{~mm}$ and hardness HV 155) was examined by straining [8-10]. The obtained value was $R_{m}=610 \mathrm{MPa}$, and the relative elongation $A_{100}=35 \%$. The hardness of samples increases monotonically from $155 \mathrm{HV}$ in a molten state, up to $316 \mathrm{HV}$ after 8 reductions in rolling mills, with the total degree of deformation increasing up to $71.74 \%$ (Table 1). After the first annealing hardness decreases to $183 \mathrm{HV}$, and with subsequent cold deformation, after 3 reductions in rolling mills, increases monotonically up to $314 \mathrm{HV}$ with the increase of the degree of cold deformation to $91.74 \%$. After the second annealing, the hardness of the sample decreases to $160 \mathrm{HV}$ with the increase of the degree of cold deformation to $70.70 \%$ [11-13].

PCA performs reductions of data matrix by transforming the data into orthogonal components (F1-F4) that represent a linear combination of the original variables (samples I-XII from Table 1). Before applying PCA analysis, we tested the data matrix in order to detect outliers. Application of Grubb's 
test to experimental data resulted in the detection of no outliers in the datasets (the critical value for $\alpha=0.05$ and $n=12$ was 2.412 ). Strong positive correlations were observed between data of Width (b) and Hardness (HV10) $(r=0.833)$, Width (b) and Electrical conductivity (MS/m) ( $r=0.823)$, and Hardness (HV10) and Electrical conductivity $(\mathrm{MS} / \mathrm{m})(\mathrm{r}=0.989)$; and strong negative correlations between Width (b) and Height $(\mathrm{h})(\mathrm{r}=-0.980)$, Height $(\mathrm{h})$ and Hardness (HV10) $(r=-0.887)$, and Height $(h)$ and Electrical conductivity $(M S / m)(r=-0.867)[14,15]$. From the shape of the scree plot, shown in Fig. 1a, the number of important components that will be used in further calculations can be observed.

Table 1. The ratio of elongation, hardness and electrical conductivity for the alloy Au585Cu233Ni80Zn70Pd32, depending on the degree of reduction

\begin{tabular}{|l|l|l|l|l|l|l|l|}
\hline Sample & $\begin{array}{c}\text { Width } \\
(\mathrm{b})(\mathrm{mm})\end{array}$ & $\begin{array}{c}\text { Height } \\
(\mathrm{h})(\mathrm{mm})\end{array}$ & $\varepsilon$ total & $\varepsilon_{\text {individually }}$ & $\mathrm{F}_{0} / \mathrm{F}$ & $\begin{array}{c}\text { Hardness } \\
(\mathrm{HV} 10)\end{array}$ & $\begin{array}{c}\text { Electrical } \\
\text { conductivity } \\
(\mathrm{MS} / \mathrm{m})\end{array}$ \\
\hline $\mathrm{I}$ & 28.3 & 4.6 & & & & 155 & 5.83 \\
\hline II & 28.4 & 4.4 & $4.35 \%$ & $4.35 \%$ & 1.0454 & 162 & 5.86 \\
\hline III & 28.6 & 4.1 & $10.87 \%$ & $6.81 \%$ & 1.1219 & 174 & 5.88 \\
\hline IV & 28.7 & 3.6 & $21.74 \%$ & $12.19 \%$ & 1.2778 & 209 & 5.91 \\
\hline V & 28.8 & 3.1 & $32.61 \%$ & $13.89 \%$ & 1.4839 & 244 & 5.97 \\
\hline VI & 29.0 & 2.7 & $41.30 \%$ & $12.90 \%$ & 1.7037 & 263 & 6.00 \\
\hline VII & 29.1 & 2.2 & $52.17 \%$ & $18.52 \%$ & 2.0909 & 276 & 6.03 \\
\hline VIII & 29.2 & 1.7 & $63.04 \%$ & $22.73 \%$ & 2.7058 & 298 & 6.08 \\
\hline IX & 29.4 & 1.3 & $71.74 \% / 0 \%$ & $23.53 \%$ & 3.5385 & $316 / 183^{\mathrm{A}}$ & $6.12 / 5.89^{\mathrm{A}}$ \\
\hline $\mathrm{X}$ & 29.6 & 0.86 & $81.30 \% / 33.85 \%$ & $33.85 \%$ & 5.3489 & 247 & 5.96 \\
\hline XI & 29.9 & 0.58 & $87.39 \% / 55.38 \%$ & $32.56 \%$ & 7.9310 & 280 & 6.05 \\
\hline XII & 30.1 & 0.38 & $91.74 \% / 70.70 \%$ & $34.48 \%$ & 12.1053 & $314 / 160^{\mathrm{A}}$ & $6.11 / 5.85^{\mathrm{A}}$ \\
\hline
\end{tabular}

A values after annealing, $\mathrm{T}=650^{\circ} \mathrm{C}, \mathrm{t}=10 \mathrm{~min}$.

${ }^{B}$ sample was taken for wire making.

PCA of dataset revealed the presence of one component with characteristic value (3.690) exceeding 1, explaining $92.249 \%$ of the variability. Based on the Kaiser criterion [16], two components (F1 and F2) will be used in further explanations of variances. This two-component solution explained a total of $99.354 \%$ of the variance, with the contribution of the first component of $92.249 \%$, and the second component of $7.105 \%$. Since two-component solution based on the Kaiser criterion explained $99.354 \%$ of the total variability, this criterion was accepted. Observation plot based on the contents of components is represented in Fig. 2a. 
MLADEN MIRIĆ, BILJANA ARSIĆ, MILOŠ ĐORĐEVIĆ, DRAGAN ĐORĐEVIĆ, DRAGOSLAV GUSKOVIĆ, SVETLANA IVANOV
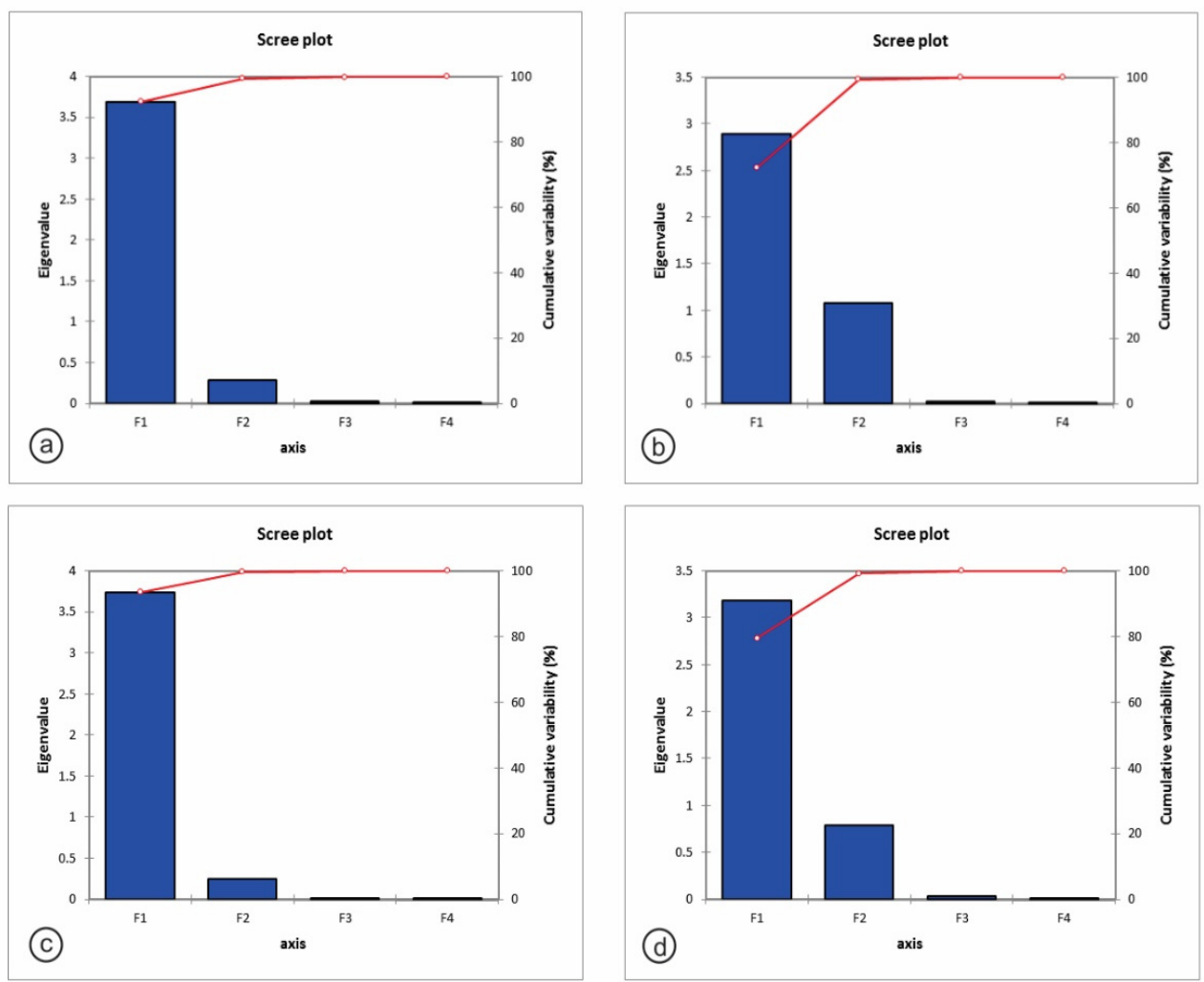

Figure 1. Scree plots of Eigen values

The high value of Width (b) is present in samples on the right side of the plot and low on the left side of the plot. Also, it can be concluded that high value of Height $(\mathrm{h})$ is present in samples in the upper half of the plot and low on the opposite side of the plot (Fig. 2a).

The hardness of samples increases from $174 \mathrm{HV}$ after forming the tube and welding, to $248 \mathrm{HV}$ after 4 drawings at a tow bench and with increasing of the total coefficient of elongation to 1.1133 (Table 2). After interphase annealing hardness decreases to $181 \mathrm{HV}$, and with subsequent cold deformation after 3 drawings on the tow bench increases to $241 \mathrm{HV}$, with the increase of total coefficient of elongation to $1.406612[11-13,17,18]$. The cold-rolled sheet of alloy Au585Cu312Zn40Ga35In28 with the hardness of HV 150 of thickness $0.38 \mathrm{~mm}$ was examined by straining [8-10]. The obtained value is $R_{m}=590 \mathrm{MPa}$, while the relative elongation is $\mathrm{A}_{100}=34 \%$. Before applying PCA analysis on the dataset, we examined the data matrix in order to detect outliers. Application of Grubb's test to experimental data resulted in the detection of no outliers in 
PRINCIPAL COMPONENT ANALYSIS AND THERMOMECHANICAL PREFERENCE OF WHITE AU ALLOYS WITHOUT Ag

Table 2. The ratio of elongation and hardness for a tube of alloy

Au585Cu233Ni80Zn70Pd32, depending on the reduction degree

\begin{tabular}{|l|l|l|l|l|l|l|}
\hline Sample & $\begin{array}{c}\text { Length } \\
(\mathrm{I})(\mathrm{mm})\end{array}$ & $\begin{array}{c}\text { Diameter } \\
(\varnothing)(\mathrm{mm})\end{array}$ & \multicolumn{1}{|c|}{$\lambda_{\text {individually }}$} & $\lambda_{\text {total }}$ & \multicolumn{1}{|c|}{$\begin{array}{c}\text { Hardness } \\
(\mathrm{HV} 10)\end{array}$} & $\begin{array}{c}\text { Electrical } \\
\text { conductivity } \\
(\mathrm{MS} / \mathrm{m})\end{array}$ \\
\hline $\mathrm{I}$ & 150 & 6.0 & & & 174 & 5.88 \\
\hline $\mathrm{II}$ & 152 & 5.8 & 1.0133 & 1.0133 & 187 & 5.90 \\
\hline $\mathrm{III}$ & 157 & 5.6 & 1.0328 & 1.0466 & 208 & 5.92 \\
\hline $\mathrm{IV}$ & 163 & 5.2 & 1.0382 & 1.0866 & 230 & 5.94 \\
\hline $\mathrm{V}$ & 167 & 4.8 & 1.0245 & 1.1133 & $248 / 181^{\mathrm{A}}$ & $5.96 / 5.89$ \\
\hline $\mathrm{VI}$ & 180 & 4.6 & 1.0778 & 1.2000 & 200 & 5.90 \\
\hline VII & 193 & 4.3 & 1.0722 & 1.2866 & 210 & 5.91 \\
\hline VIII & 211 & 3.9 & 1.0932 & 1.4066 & 241 & 5.93 \\
\hline
\end{tabular}

A hardness of tubes after annealing

the datasets (the critical value for $\alpha=0.05$ and $n=8$ was 2.127 ). Strong positive correlations were observed between Hardness (HV10) and Electrical conductivity $(\mathrm{MS} / \mathrm{m})(\mathrm{r}=0.947)$; and strong negative correlations between Length $(\mathrm{I})$ and Diameter $(\varnothing)(r=-0.980)[14,15]$. From the shape of the scree plot, shown in Fig. 1b, the number of important components that will be used in further calculations can be observed (F1 and F2). PCA of dataset revealed the presence of two components with characteristic values (2.890 and 1.082) exceeding 1 , explaining $99.282 \%$ of variability. Based on the Kaiser criterion [16], two components will be used in further explanations of variances. This two-component solution explained a total of $99.282 \%$ of the variance, with the contribution of the first component of $72.244 \%$, and the second component of $27.038 \%$. Since two-component solution based on the Kaiser criterion explained $99.282 \%$ of the total variability, this criterion was accepted. Observation plot based on the contents of components is represented in Fig. $2 \mathrm{~b}$. The high value of Length (I) is present in samples on the right side of the plot and low on the left side of the plot. Also, it can be concluded that high value of Diameter $(\varnothing)$ is present in samples in the upper half of the plot and low on the opposite side of the plot (Fig. 2b). The hardness of samples increases from $150 \mathrm{HV}$ in a molten state, up to $310 \mathrm{HV}$ after 7 reductions in rolling mills while the total degree of deformation increased to $73.91 \%$ (Table 3).

After the first annealing, hardness decreases to $180 \mathrm{HV}$, and with subsequent cold deformation, after 3 reductions in rolling mills increases to $305 \mathrm{HV}$ with the degree of cold deformation increasing to $91.74 \%$. After the second annealing, the hardness of samples decreases to $150 \mathrm{HV}$ with increasing degree of cold deformation to $68.33 \%$ [8-10]. Application of Grubb's test for 
MLADEN MIRIĆ, BILJANA ARSIĆ, MILOŠ ĐORĐEVIĆ, DRAGAN ĐORĐEVIĆ, DRAGOSLAV GUSKOVIĆ, SVETLANA IVANOV

the detection of outliers to experimental data (samples I-XI from Table 3) resulted in the detection of no outliers in the datasets (the critical value for $\alpha=0.05$ and $n=11$ was 2.355). Strong positive correlations were observed between data of Width (b) and Hardness (HV10) $(r=0.891)$, Width (b) and Electrical conductivity $(\mathrm{MS} / \mathrm{m})(\mathrm{r}=0.843)$, and Hardness (HV10) and Electrical conductivity $(\mathrm{MS} / \mathrm{m})(\mathrm{r}=0.985)$; and strong negative correlations between Width (b) and Height $(\mathrm{h})(\mathrm{r}=-0.994)$, Height $(\mathrm{h})$ and Hardness (HV10) ( $\mathrm{r}=-0.905)$, and Height $(\mathrm{h})$ and Electrical conductivity (MS/m) $(r=-0.854)[14,15]$.

Table 3. The ratio of elongation, hardness and electrical conductivity of alloy Au585Cu312Zn40Ga35In28, depending on the reduction degree

\begin{tabular}{|l|l|l|l|l|l|l|l|}
\hline Sample & $\begin{array}{c}\text { Width } \\
(\mathrm{b})(\mathrm{mm})\end{array}$ & $\begin{array}{c}\text { Height } \\
(\mathrm{h})(\mathrm{mm})\end{array}$ & $\varepsilon$ total & $\varepsilon_{\text {individually }}$ & $\mathrm{F}_{0} / \mathrm{F}$ & $\begin{array}{c}\text { Hardness } \\
(\mathrm{HV} 10)\end{array}$ & $\begin{array}{c}\text { Electrical } \\
\text { conductivity } \\
(\mathrm{MS} / \mathrm{m})\end{array}$ \\
\hline I & 28.6 & 4.6 & & & & 150 & 5.80 \\
\hline II & 28.7 & 4.3 & $6.52 \%$ & $6.52 \%$ & 1.0697 & 156 & 5.82 \\
\hline III & 28.9 & 3.9 & $15.22 \%$ & $9.30 \%$ & 1.1795 & 172 & 5.87 \\
\hline IV & 29.1 & 3.4 & $26.09 \%$ & $12.82 \%$ & 1.3529 & 204 & 5.90 \\
\hline V & 29.3 & 2.7 & $41.30 \%$ & $20.59 \%$ & 1.7037 & 243 & 5.94 \\
\hline VI & 29.6 & 2.1 & $54.35 \%$ & $22.22 \%$ & 2.1905 & 268 & 6.01 \\
\hline VII & 29.8 & 1.6 & $65.22 \%$ & $23.81 \%$ & 2.8750 & 290 & 6.06 \\
\hline VIII & 29.9 & 1.2 & $73.91 \% / 0 \%$ & $25.00 \%$ & 3.8333 & $310 / 180^{\mathrm{A}}$ & $6.11 / 5.88$ \\
\hline IX & 30.1 & 0.8 & $82.61 \% / 33.33 \%$ & $33.33 \%$ & 5.7500 & $240^{\mathrm{B}}$ & 5.93 \\
\hline X & 30.3 & 0.5 & $89.13 \% / 58.33 \%$ & $37.50 \%$ & 9.2000 & 275 & 6.02 \\
\hline XI & 30.5 & 0.38 & $91.74 \% / 68.33 \%$ & $24.00 \%$ & 12.1052 & $305 / 150^{\mathrm{A}}$ & $6.07 / 5.81^{\mathrm{B}}$ \\
\hline
\end{tabular}

${ }^{A}$ values after annealing, temperature $650^{\circ} \mathrm{C}, \mathrm{t}=10 \mathrm{~min}$.

${ }^{\mathrm{B}}$ sample was taken for wire making.

From the shape of the scree plot, shown in Fig. 1c, the number of important components that will be used in further calculations can be observed (F1 and F2). PCA of dataset revealed the presence of one component with characteristic value (3.736) exceeding 1, explaining $93.4 \%$ of the variability. Based on the Kaiser criterion [16], two components will be used in further explanations of variances. This two-component solution explained a total of $99.619 \%$ of the variance, with the contribution of the first component of $93.4 \%$, and the second component of $6.218 \%$. Since two-component solution based on the Kaiser criterion explained $99.619 \%$ of the total variability, this criterion was accepted. Observation plot based on the contents of components is represented in Fig. 2c. 

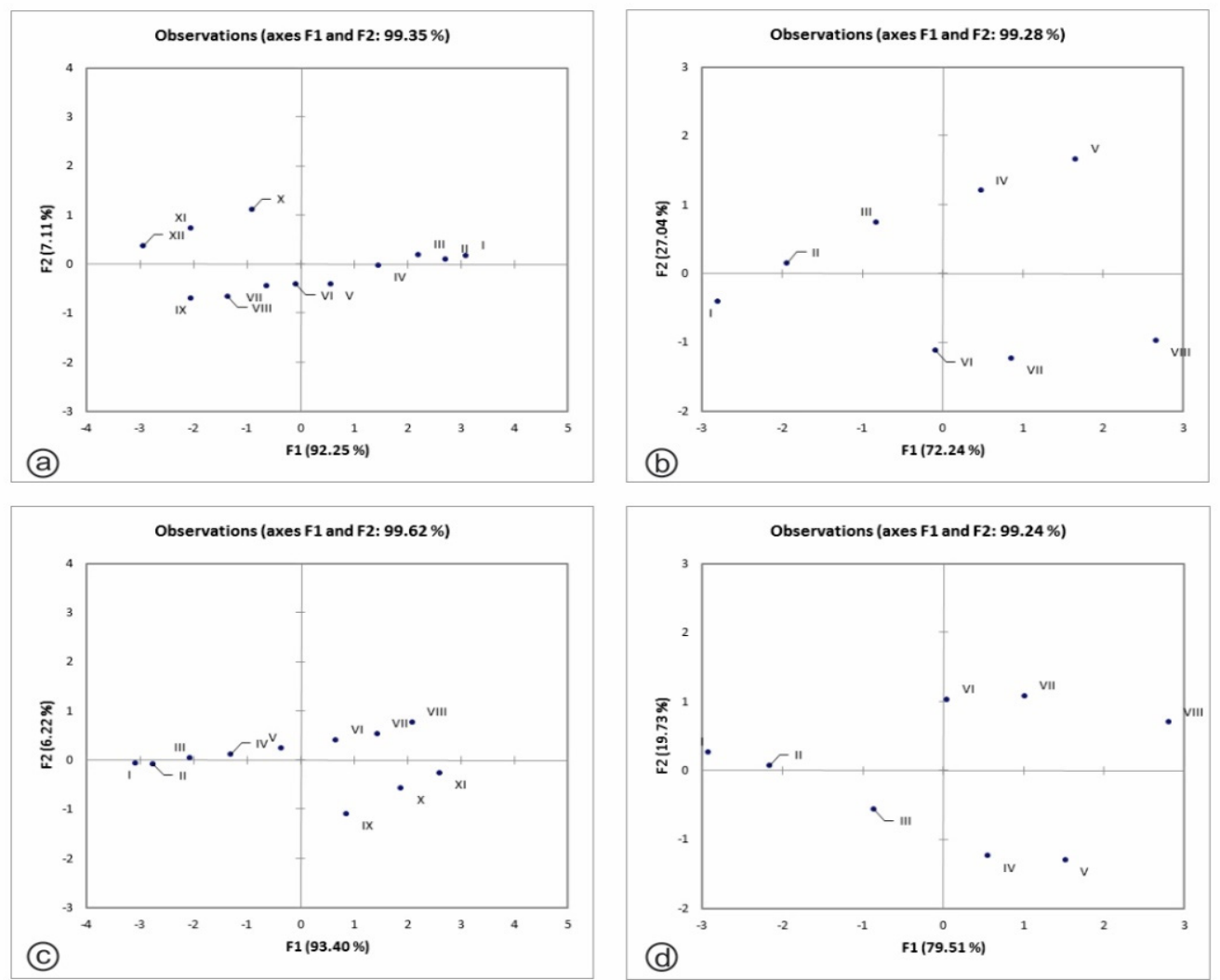

Figure 2. Principal component score plots (F1 and F2) of the studied samples

The high value of Width (b) is present in samples on the right side of the plot and low on the left side of the plot (Fig. 2c). Also, it can be concluded that high value of Height $(\mathrm{h})$ is present in samples in the upper half of the plot and low on the opposite side of the plot.

The hardness of samples increases from $170 \mathrm{HV}$ after forming the pipe and welding, up to $240 \mathrm{HV}$ after 4 drawings at a tow bench with the increase of the total coefficient of elongation to 1.1400 (Table 4). After the interphase annealing hardness decreases to $171 \mathrm{HV}$, and with subsequent cold deformation after 3 drawings on the tow bench increases to $238 \mathrm{HV}$ with the increase of the total coefficient of elongation to 1.4266 [8-10].

Application of Grubb's test to experimental data (samples I-VIII from Table 4) resulted in the detection of no outliers in the datasets (the critical value for $\alpha=0.05$ and $n=8$ was 2.127 ). Strong positive correlations were observed 
MLADEN MIRIĆ, BILJANA ARSIĆ, MILOŠ ĐORĐEVIĆ, DRAGAN ĐORĐEVIĆ, DRAGOSLAV GUSKOVIĆ, SVETLANA IVANOV

between data of Hardness (HV10) and Electrical conductivity (MS/m) ( $r=0.988)$; and strong negative correlations between Length $(\mathrm{I})$ and Diameter $(\varnothing)(\mathrm{r}=-0.958)$, and Hardness (HV10) and Diameter $(\varnothing)(r=-0.715)[14,15]$.

Table 4. The ratio of elongation and hardness of alloy Au585Cu312Zn40Ga35In28 tube depending on the reduction degree

\begin{tabular}{lcccccc}
\hline Sample & $\begin{array}{c}\text { Length } \\
(\mathrm{I})(\mathrm{mm})\end{array}$ & $\begin{array}{c}\text { Diameter } \\
(\varnothing)(\mathrm{mm})\end{array}$ & $\lambda_{\text {individually }}$ & $\lambda_{\text {total }}$ & $\begin{array}{c}\text { Hardness } \\
(\mathrm{HV} \mathrm{10})\end{array}$ & $\begin{array}{c}\text { Electrical } \\
\text { conductivity } \\
(\mathrm{MS} / \mathrm{m})\end{array}$ \\
\hline I & 150 & 6.0 & & & 170 & 5.87 \\
II & 153 & 5.7 & 1.0200 & 1.0200 & 180 & 5.88 \\
III & 158 & 5.4 & 1.0326 & 1.0533 & 202 & 5.90 \\
IV & 164 & 5.1 & 1.0379 & 1.0933 & 228 & 5.92 \\
V & 171 & 4.7 & 1.0426 & 1.1400 & $240 / 171^{\mathrm{A}}$ & $5.93 / 5.88$ \\
VI & 183 & 4.5 & 1.0701 & 1.2200 & 198 & 5.89 \\
VII & 195 & 4.2 & 1.0655 & 1.3000 & 208 & 5.90 \\
VIII & 214 & 3.9 & 1.0974 & 1.4266 & 238 & 5.92 \\
\hline
\end{tabular}

${ }^{A}$ hardness of tubes after annealing

From the shape of the scree plot, shown in Fig. 1d, the number of important components that will be used in further calculations can be observed (F1 and F2). PCA of dataset revealed the presence of one component with characteristic value (3.181) exceeding 1, explaining $79.513 \%$ of the variability. Based on the Kaiser criterion [16], two components will be used in further explanations of variances. This two-component solution explained a total of $99.244 \%$ of the variance, with the contribution of the first component of $79.513 \%$, and the second component of $19.731 \%$. Since two-component solution based on the Kaiser criterion explained $99.244 \%$ of the total variability, this criterion was accepted. Observation plot based on the contents of components is represented in Fig. 2d. The high value of Length $(\mathrm{I})$ is present in samples on the right side of the plot and low on the left side of the plot (Fig. 2d). Also, it can be concluded that high value of Diameter $(\varnothing)$ is present in samples in the upper half of the plot and low on the opposite side of the plot.

The microstructure of cold-rolled sample of alloy Au585Cu233Ni80Zn70Pd32 (the overall reduction degree $71.74 \%$, the hardness of $\mathrm{HV} 316$ ), was etched in the solution $10 \% \mathrm{KCN}: 10 \%\left(\mathrm{NH}_{4}\right)_{2} \mathrm{~S}_{2} \mathrm{O}_{8}$ in the ratio of $1: 1$ for $2 \mathrm{~h}$ at $40{ }^{\circ} \mathrm{C}$, at $200 \times$ magnification. Because of technological and metallurgical characteristics that are reflected in the higher hardness values, this sample is reduced 8 times at the rolling stands. The grains are elongated and oriented in the direction of the deformation (Figure 3a) [8-10,13]. 


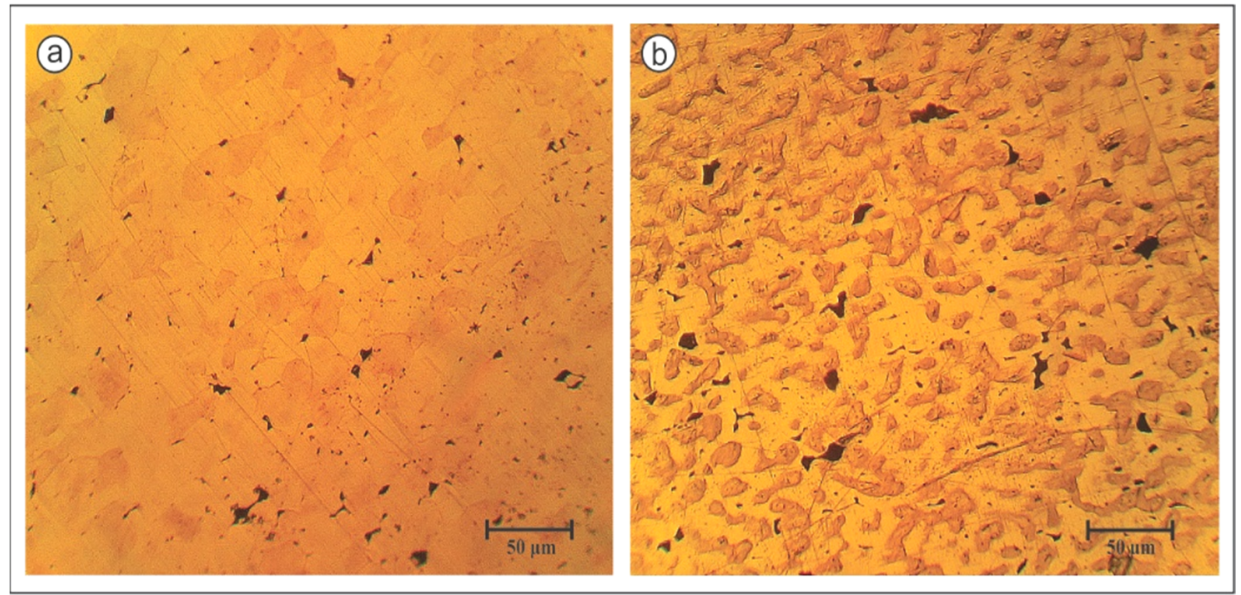

Figure 3. The pattern of alloy Au585Cu233Ni80Zn70Pd32 a) after 8 reductions of hardness $\mathrm{HV} 316, \varepsilon=71.74 \%$ etched in the solution of $10 \% \mathrm{KCN}: 10 \%\left(\mathrm{NH}_{4}\right)_{2} \mathrm{~S}_{2} \mathrm{O}_{8}$ in the ratio of $1: 1$ for $2 \mathrm{~h}$ at $40{ }^{\circ} \mathrm{C}$, at $200 \times$ magnification, b) etched in the solution of $8 \mathrm{ml}$ of distilled $\mathrm{H}_{2} \mathrm{O}, 3 \mathrm{ml}$ of $\mathrm{HCl}$ and $\mathrm{HNO}_{3}$ in $1 \mathrm{ml}$ where $2 \mathrm{~g} \mathrm{CrO}_{2}$ was added

The microstructure of annealed samples of white gold with nickel obtained by SEM method, magnified 500 times, where the points 2, 4 and 5, residing in the light phase, have less copper than the points 1 and 3 , residing in the darker phase (Figure 4). Two distinct phases coexist, where the lighter contains a higher percentage of gold and a small percentage of copper, while the darker contains a lower percentage of gold and a higher percentage of copper.

Figure 5a shows the microstructure of cold-rolled sample with the overall reduction degree of $74.47 \%$. The sample was reduced 7 times at the rolling stands, and a sample of white gold without nickel shows hardness values lower than the white gold alloy with nickel $[8-10,13,19]$. The grains are elongated and oriented in the direction of the deformation. There is also the occurrence of twin crystals and phases [12]. Figure $5 b$ shows the sample from Figure 6a, which is annealed at a constant temperature of $923 \mathrm{~K}\left(650^{\circ} \mathrm{C}\right)$ for $10 \mathrm{~min}$. It can be observed the recrystallised structure of the multi-component system that is ready for further deformation [12]. 
MLADEN MIRIĆ, BILJANA ARSIĆ, MILOŠ ĐORĐEVIĆ, DRAGAN ĐORĐEVIĆ, DRAGOSLAV GUSKOVIĆ, SVETLANA IVANOV

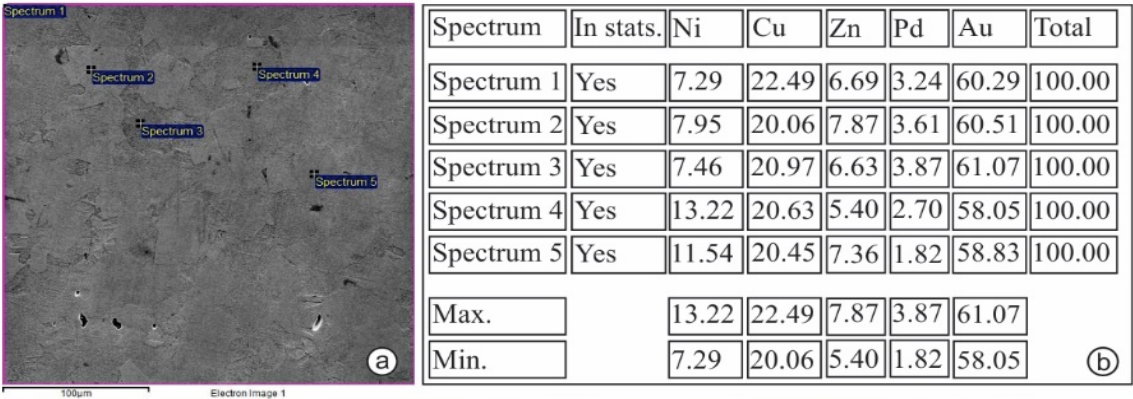

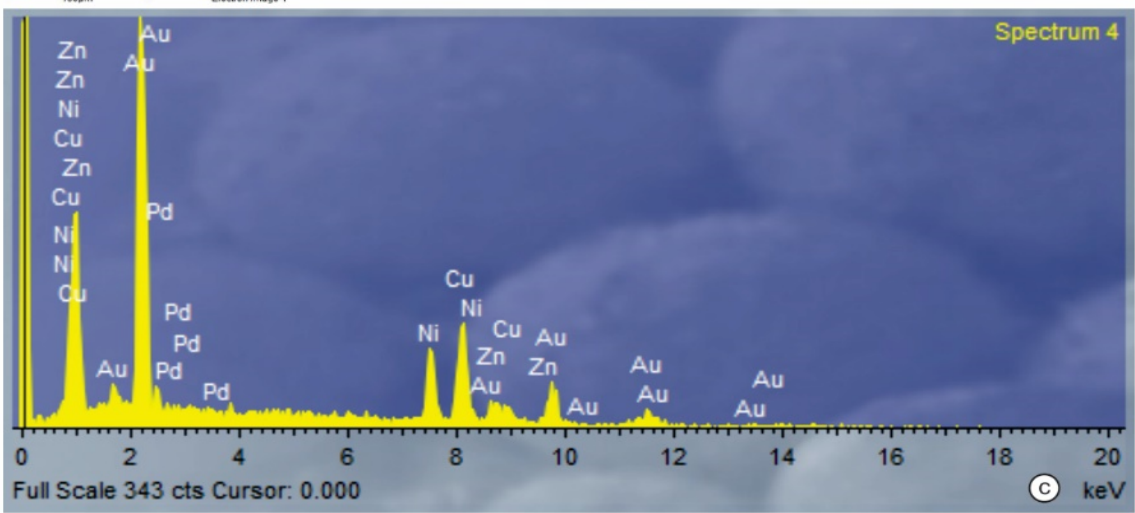

Figure 4. The microstructure of annealed samples of white gold with nickel: a) Overview of points for chemical composition analysis, magnification 500x, b) the table showing the content of the alloy components in the individual points, c) EDS spectrum analysis of point 4

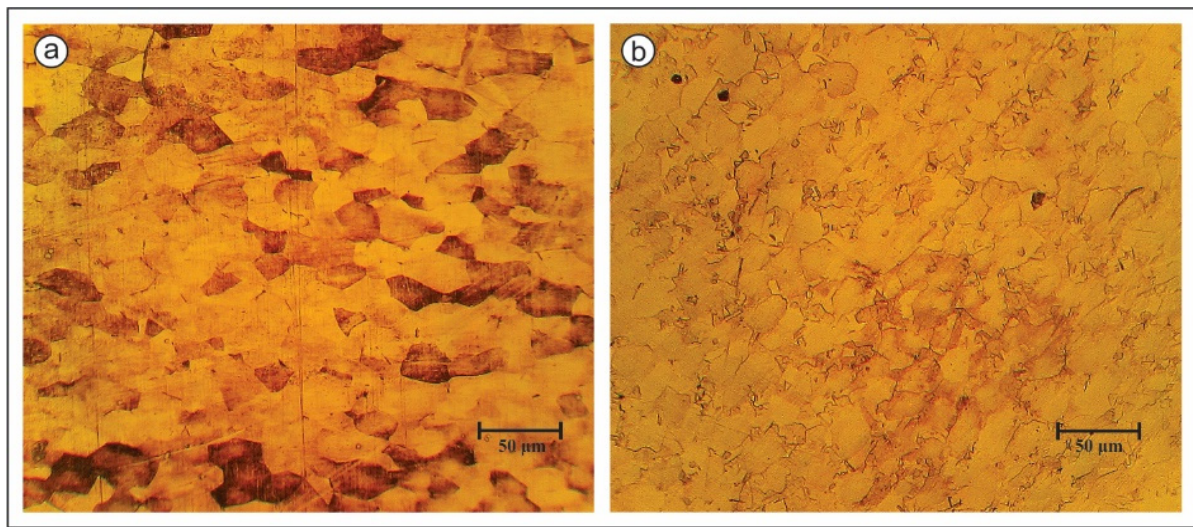

Figure 5. Pattern of alloy Au585Cu312Zn40Ga35In28 etched in KCN solution of $10 \%: 10 \%\left(\mathrm{NH}_{4}\right)_{2} \mathrm{~S}_{2} \mathrm{O}_{8}$ in the ratio of $1: 1$ for 2 hours at $40{ }^{\circ} \mathrm{C}, 200 x$ magnification: a) after 7 reduction of hardness $\mathrm{HV} 313, \varepsilon=74.47 \%$, b) after the first annealing with hardness HV 180 
Figure 6 shows the microstructure of annealed recrystallised samples of the Au585Cu312Zn40Ga35In28 alloy obtained by SEM method with a magnification of 500 times, where it can be seen that points 1 and 2, from the lighter phase, have much less copper content than points 3 and 4 , from the darker phase. Two different phases coexist, where the lighter one contains greater $\%$ of gold and lower $\%$ of copper, while the dark has lower $\%$ of gold and higher $\%$ of copper.

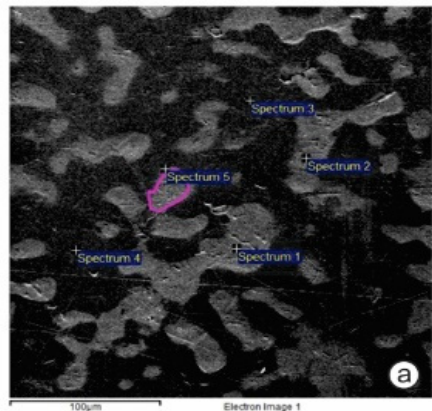

\begin{tabular}{|l|l|l|l|l|l|l|l|l|l|}
\hline Spectrum & In stats. & $\mathrm{Cu}$ & $\mathrm{Zn}$ & $\mathrm{Ga}$ & In & Au & Total \\
\hline Spectrum 1 & Yes & 0.72 & 0.93 & 0.81 & 0.69 & 96.85 & 100.00 \\
\hline Spectrum 2 & Yes & 4.43 & 1.00 & 0.93 & 0.60 & 93.05 & 100.00 \\
\hline Spectrum 3 & Yes & 27.80 & 3.71 & 2.18 & 1.81 & 64.50 & 100.00 \\
\hline Spectrum 4 & Yes & 29.92 & 3.28 & 2.44 & 1.53 & 62.83 & 100.00 \\
\hline Spectrum 5 & Yes & & & & 100.00 & 100.00 \\
\hline Max. & & 29.92 & 3.71 & 2.44 & 1.81 & 62.83 & \\
\cline { 1 - 1 } Min. & 0.72 & 0.93 & 0.81 & 0.60 & 100.00 & (b) \\
\hline
\end{tabular}

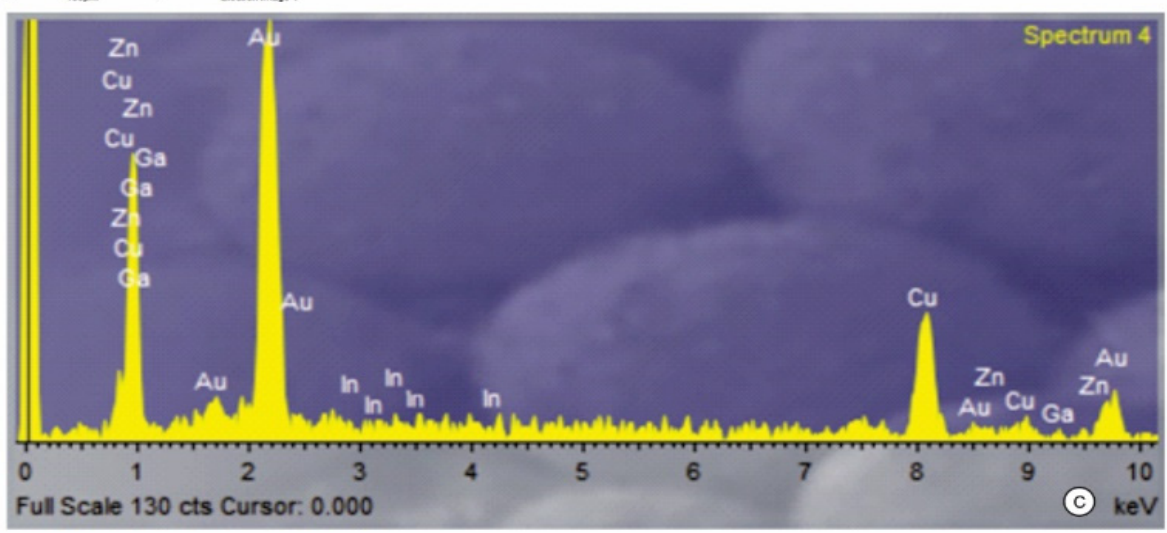

Figure 6. The microstructure of annealed recrystallised samples of Au585Cu312Zn40Ga35In28: a) Overview of points for chemical composition analysis, magnification $500 \times$, b) the table shows the content of the alloy components in the individual points, c) EDS spectrum analysis of point 4

\section{CONCLUSIONS}

By rolling cast pieces of the white gold alloy without silver, high-quality rectangular profiles of flat-sheet-strips with smooth edges, without cracks, uniform thickness and width all along the length, were obtained. Using the method of 
MLADEN MIRIĆ, BILJANA ARSIĆ, MILOŠ ĐORĐEVIĆ, DRAGAN ĐORĐEVIĆ, DRAGOSLAV GUSKOVIĆ, SVETLANA IVANOV

cold rolling, with the increase in the total strain, the curves for the hardness value show the increase for both types of samples, more for the alloy Au585Cu233Ni80Zn70Pd32 than for the alloy Au585Cu312Zn40Ga35In28. The values obtained for the tensile strength in both tested alloys are at the upper limit of the literature values, while the relative elongation values are in the field of expected values. The values of electrical conductivity and hardness are different, due to the reduction, which was shown using PCA ( $r=0.985$ and the strong positive correlation between hardness and electrical conductivity). Annealing under these conditions does not achieve the desired recrystallised structure. It is concluded that it is necessary for this white gold alloy to be annealed for a longer period or at a higher temperature. The microstructure of this alloy type, analyzed by optical and scanning electron microscopy - SEM, shows that during the metallurgical processes, micro-structural changes of structures happened. The processes of crystal grains fragmentation play an important role in the grain boundary dislocations, impurities, and intermetallic compounds.

\section{EXPERIMENTAL SECTION}

Sample preparation was performed in an induction furnace graphite ladle (the processes of heating, melting, mixing and production). The resulting mixture was discharged into the wax-coated molds and casts of dimensions: $92 \mathrm{~mm} \times 28.6 \mathrm{~mm} \times 4.6 \mathrm{~mm}$ (Au585Cu312Zn40Ga35In28) and $92 \mathrm{~mm} \times 28.3$ $\mathrm{mm} \times 4.6 \mathrm{~mm}$ (Au585Cu233Ni80Zn70Pd32). The resulting cast was several times on rolling stands (after every 5 passes it was annealed-recrystallised at $650{ }^{\circ} \mathrm{C}$ for $10 \mathrm{~min}$ ) to achieve the appropriate sheet thickness- $0.38 \mathrm{~mm}$, which was suitable for cutting using circular shears.

Obtained strip (thickness $0.38 \mathrm{~mm}$ and a width $18.5 \mathrm{~mm}$ ) was passed through the device for resistance welding in the presence of argon. The entire scheme of sampling is shown in Figures $7 \mathrm{a}$ and $7 \mathrm{~b}$.

Qualitative determination of the composition of the examined alloys using XRF device was performed in the Laboratory of the Directorate of Measures and Precious Metals in Belgrade, Republic of Serbia. Several investigations (hardness testing of samples, tensile testing, metallographic investigations, investigations using scanning electron microscopy and energy-dispersive spectroscopy, determination of electrical conductivity and determination of the colour of tested alloys) were conducted in the Laboratories of the Technical Faculty in Bor, Republic of Serbia [20-26]. 

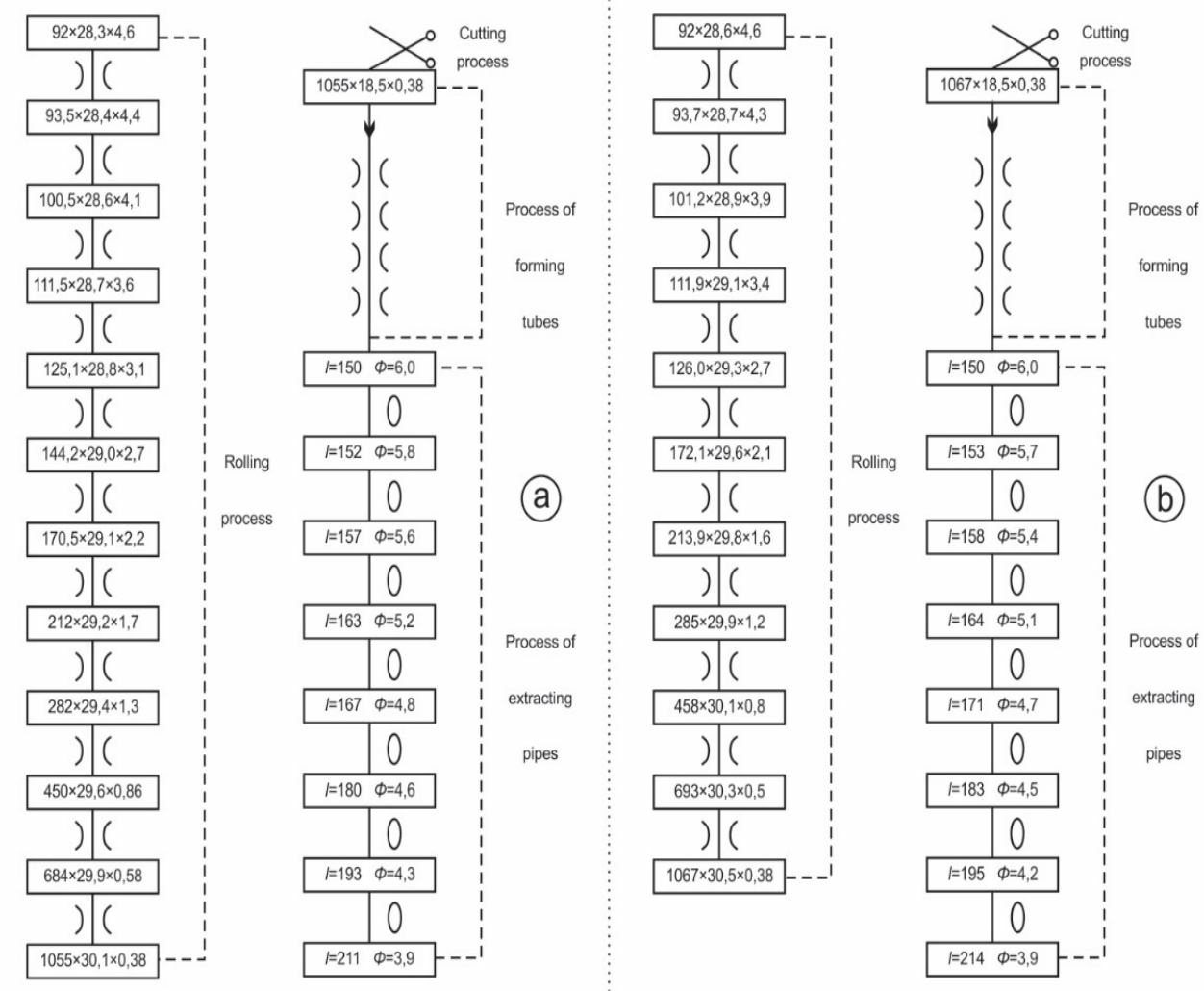

Figure 7. a) Pass plan for the alloys Au585Cu233Ni80Zn70Pd32,

b) Au585Cu312Zn40Ga35In28

\section{Statistical analysis (Principal component analysis)}

The principal component analysis was used with the aim to evaluate the dataset, reducing its dimension and conserving most of the statistical information. PCA permits establishing the relationships among variables. The analysis was performed using statistical application available for Microsoft Excel $^{\circledR}$ (XLSTAT 2015.6.01.24412, Addinsoft SARL, Paris, France) [27].

\section{ACKNOWLEDGMENTS}

Dr Biljana Arsic wants to thank for financial support for this research to Ministry of Science, Education and Technological Development of Republic of Serbia (project no. 174007). 
MLADEN MIRIĆ, BILJANA ARSIĆ, MILOŠ ĐORĐEVIĆ, DRAGAN ĐORĐEVIĆ, DRAGOSLAV GUSKOVIĆ, SVETLANA IVANOV

\section{REFERENCES}

1. Direttiva 2004/96/CE della Commisione, Gazzetta ufficiale dell'Unione europea journal, L 301/51, 27 settembre 2004. http://eur-lex.europa.eu/legal-content/IT/ TXT/?uri=CELEX\%3A32004L0096

2. Direttiva 2002/96/CE del Parlamento Europeoe del Consiglio, Gazzetta ufficiale dell'Unione europea journal, L 37/24, 27 gennaio 2003. http://eur-lex.europa.eu/ legal-content/IT/TXT/?uri=CELEX\%3A52003PC0723

3. J. Shlens; A Tutorial on Principal Component Analysis, Salk Institute for Biological Studies and Institute for Nonlinear Science: San Diego, USA, 2005.

4. J. D. Horel; J. M. Wallace; Mon. Weather Rev., 1981, 109, 2080-2092.

5. M. C. Janzen; J. B. Ponder; D. P. Bailey; C. K. Ingison; K. S. Suslick; Anal. Chem., 2006, 78, 3591-3600.

6. P. Jolicoeur; J. E. Mosimann; Growth, 1960, 24, 339-354.

7. S. Wold; K. Esbensen; P. Geladi; Chemometr. Intell. Lab., 1987, 2, 37-52.

8. M. B. Mirić; R. S. Perić; S. P. Dimitrijević; S. A. Mladenović; S. R. Marjanović; Bulg. Chem. Commun., 2015, 47, 161-166.

9. M. Mirić; D. Marković; D. Gusković; 38th International October Conference on Mining and Metallurgy, 2006, 280-285.

10. M. Mirić; D. Gusković; S. Ivanov; S. Marjanović; S. Mladenović; Metalurgia Int., 2013, $18,47-50$.

11. D. Ott; Gold Bull., 2000, 33, 25-32.

12. D. Gusković; D. Marković; S. Ivanov; S. Nestorović; M. Mirić; International Research/ Expert Conference $15^{\text {th }}$ Trends in the Development of Machinery and Associated Technology", Eds. by S. Ekinović, J. Vivancos Calvet, E. Tacer, TMT, Prague, 2011, 713-716.

13. J. Fischer-Bühner; A. Basso; M. Poliero; Gold Bull., 2010, 43, 11-20.

14. S. Shrestha; F. Kazama; Environ. Modell. Softw., 2007, 22, 464-475.

15. M. Varol; B. Gokot; A. Bekleyen; B. Sen; Catena, 2012, 92, 11-21.

16. H. F. Kaiser; Educ. Psychol. Meas., 1960, 20, 141-151.

17. M. Kazemineshad; A. K. Taheri; Mater. Design, 2005, 26, 99-103.

18. M. Kazemineshad; A. K. Taheri; A. K. Tieu; J. Mater. Process. Tech., 2008, 200, 325-330.

19. L. Battezzati; I. Moiraghi; I. Calliari; M. Dabalà; Intermetallics, 2004, 12, 327-332.

20. http://xrf-spectroscopy.com/

21. B. Hafner; Scanning Electron Microscopy Primer-Characterization Facility, Twin Cities, Minnesota, 2007.

22. R. A. Schwarzer; D. P. Field; B. L. Adams; M. Kumar; A. J. Schwartz; In Electron backscatter diffraction in materials science; A. J. Schwartz, M. Kumar, B. L. Adams, D. P. Field Eds.; Springer: US, 2009, pp. 1-20.

23. http://www.charfac.umn.edu/instruments/eds_on_sem_primer.pdf

24. H. Šuman; Metalografija; TMF: Belgrade, $19 \overline{81}$.

25. R. G. Kuehni; Color Res. Appl., 2002, 27, 126-127.

26. http://www.foerstergroup.de/SIGMATEST.171.0.html

27. https://www.xlstat.com/en/ 